Journal of Agricultural Sciences
(Tarim Bilimleri Dergisi)

\title{
Determining Factors Affecting Cooperative Membership of the Beekeepers Using Decision Tree Algorithms
}

\author{
Tayfun ÇUKUR ${ }^{a^{*}}\left(\mathbb{D}\right.$, Figen ÇUKUR ${ }^{b}$ (i)

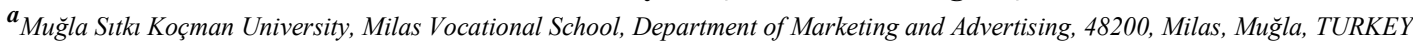

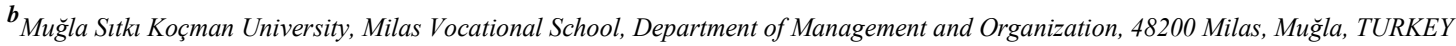 \\ ARTICLE INFO \\ Research Article \\ Corresponding Author: Tayfun ÇUKUR, E-mail: tayfun.cukur@hotmail.com \\ Received: 18 May 2020 / Revised: 22 June 2020 / Accepted: 29 September 2020 / Online: 20 January 2022
}

\section{ABSTRACT}

Agricultural cooperatives have important contributions to farmers. Thanks to cooperatives, agricultural products are sold at high prices, while agricultural inputs can be purchased at low prices. Cooperatives provide their partners with technical support in product processing, grading, standardization, storage and quality. On the other hand, cooperatives contribute to the sustainability of agricultural activities by providing credit support to their members. The current research was carried out Milas district of Muğla province, which is the center of pine honey

Keywords: Beekeeping, Farmers, Data mining, Machine learning, Milas production in Turkey. In the current research, a survey was conducted face to face with 62 farmers engaged in beekeeping, and the decision tree model, which is one of the data mining methods, was used in determining the factors that affect the beekeepers' membership in cooperatives. As a result of the statistical analyses conducted, it was concluded that on the cooperative membership of beekeepers, their status of using credit, education level and status of receiving beekeeping supports have a highly significant influence.

(C) Ankara University, Faculty of Agriculture

\section{Introduction}

Agricultural cooperatives are considered as one of the most important means of improving the living levels of farmers living in rural areas, increasing the income levels of producers with limited resources and providing agricultural development and are widely used in the world. Agricultural cooperatives are one of the most important tools used in the fight against poverty in rural areas where more than $70 \%$ of the world's poor people live (Mojo et al. 2015a).

When a general evaluation is made, it can be said that farmers are members of cooperatives due to economic concerns. On the other hand, cooperatives also have non-economic social and cultural benefits (Mojo et al. 2015b). For example, cooperatives create jobs and provide quality food and services to their members (Debeb \& Haile 2016). Cooperatives contribute to the increase in productivity. Cooperatives can also reduce transaction costs (Gutierrez 2014).

Small-scale farmers are often disadvantaged in bargaining, especially in developing countries. This situation prevents farmers from reaching competitive markets (Liu 2018). Therefore, it can be said that cooperatives are more beneficial especially for small scale farmers in developing countries. Thanks to cooperatives, small-scale producers can reach the market more easily, farmers' incomes increase, product efficiency increases and production costs decrease.

Cooperatives reduce the risks that will be encountered in the market by increasing the bargaining power of economically weak individuals. Thanks to cooperatives, new market opportunities are created. On the other hand, cooperatives are effective in increasing individual capacity, improving cooperative members' revenues and leadership skills (Woldu et al. 2013). Cooperatives establish stronger social ties, solidarity, trust and partnership among their members (Gutierrez 2014). Agricultural cooperatives play an important role in the modernization and commercialization of small-scale enterprises (Bernard \& Spielman 2009). Agricultural credit cooperatives contribute to production by giving credit to their members. On the other hand, cooperatives provide cheap agricultural inputs to their members and thus help to reduce production costs. In the study conducted by Aksoy et al. (2017), it was determined that honey productivity is high in agricultural organizations owned by beekeepers who are members of a cooperative and are engaged in migratory beekeeping.

Farmers have to make very different decisions during agricultural production. Farmers must decide the products to be obtained (honey, beeswax, bee resin, pollen, etc.) and the technology to be used (hive type). Farmers' decision to become a 
member of the cooperative is also an important decision for themselves. When the previous studies on cooperative membership are examined, it is seen that many factors affect the farmers' decision to become a member of the cooperative. In a study conducted by Karlı et al. (2006), it was determined that education level, communication level, gross income and land size affect farmers' cooperative membership. In a study conducted by Dorgi \& Gala (2016), it was found that farmers who have information about the cooperative, who use credit and who have leadership characteristics are more likely to become members of the cooperative. Balgah (2019) determined that total cultivated area, the number of households and duration of agricultural experience have an effect on farmers' cooperative membership. In the study conducted by K1z1laslan \& Gürler (1997), factors affecting the membership of the producers to a cooperative were found to be education, level of consciousness of cooperative, social status, the level of opening up to the foreign culture and the use of mass communication tools.

It is important to determine the factors that affect the decision of the beekeepers in the district of Milas to be a member of a cooperative in terms of both the development of agricultural cooperatives and the increase in the number of members of cooperatives. For this reason, the current study aims to determine the membership status of the farmers working in apiculture in the Milas district of the city of Muğla and the factors affecting their membership to cooperatives.

\section{Material and Methods}

\subsection{The method employed in the collection of the data}

The main material of the current research is made up of the data collected from the survey administered face-to-face to the participating farmers engaged in beekeeping activities in the Milas district. The main population of the study is comprised of 721 farmers engaged in beekeeping activities according to the records of the Milas Agriculture and Forestry Directorate. The survey was conducted with the farmers determined with proportional sampling volume (Genç et al. 2020; Niyaz \& Demirbaş 2018). In the study, the confidence interval is taken as $90 \%$ and error margin is taken as $10 \%$. A total of nine neighborhoods (villages) in the Milas district were included in the current study.

$$
n=\frac{N p(1-p)}{(N-1) \sigma_{P}^{2}+p(1-p)}
$$

In Equation 1; $\mathrm{n}$ : Total number of the farmers to be surveyed; $\mathrm{N}$ : Main population; $\mathrm{p}$ : is taken as 0.50 to arrive at the maximum sampling volume; $(1-\mathrm{p}): 0.5 ;{\sigma_{p x}}^{2}=$ Variance

As a result of this calculation, the total number of the farmers to be surveyed was found to be 62 . After determining the number of farmers to be surveyed, the farmers to be interviewed were randomly determined.

In the decision tree model, 13 variables that were thought to have an effect on the state of beekeepers' being a cooperative member or not were included (Table 1). 
Table 1- Variables used in the decision tree model

\begin{tabular}{|c|c|c|c|}
\hline Acronym & Variable description & Type of measure & Data type \\
\hline AGE & Beekeeper's age & $\begin{array}{l}\text { Age } \leq 40 \text { means "young" } \\
41 \leq X \leq 60 \text { means "middle-aged" } \\
\text { Age } \geq 61 \text { means "old" }\end{array}$ & Numeric \\
\hline AGREXP & $\begin{array}{l}\text { Beekeeper's agricultural } \\
\text { experience }\end{array}$ & $\begin{array}{l}\text { Experience }<21 \text { years means "little experienced" } \\
\text { Experience } 20<\mathrm{X}<40 \text { years means "moderately experienced" } \\
\text { Experience }>39 \text { years means "highly experienced" }\end{array}$ & Numeric \\
\hline NONA & Out-of agriculture income & With out-of agriculture income, without out-of agricultural income & Nominal \\
\hline HIVE & The number of hives & $\begin{array}{l}\text { The number of hives }<101 \text { means "small number of hives" } \\
\text { The number of hives } 100<X<201 \text { means "moderate number of hives" } \\
\text { The number of hives }>200 \text { means "high number of hives" }\end{array}$ & Numeric \\
\hline EDUC & Beekeeper's education level & $\begin{array}{l}\text { Period of education }<6 \text { means, "elementary school graduate" } \\
\text { Period of education } 5<\text { means "more educated" }\end{array}$ & Numeric \\
\hline CRED & Credit use & Uses credit, doesn't use credit & Nominal \\
\hline STOR & Storage of honey & Stores honey, doesn't store honey & Nominal \\
\hline INNO & Application of innovations & Applies innovations, doesn't apply innovations & Nominal \\
\hline SUPP & Receiving beekeeping supports & Receives support, doesn't receive support & Nominal \\
\hline MARK & Having access to market data & $\begin{array}{l}\text { Beekeepers can have access to market data about bee products, they cannot have } \\
\text { access to market data about bee products }\end{array}$ & Nominal \\
\hline INFO & $\begin{array}{l}\text { The state of needing } \\
\text { information about beekeeping }\end{array}$ & $\begin{array}{l}\text { Information about beekeeping is needed, information about beekeeping is not } \\
\text { needed }\end{array}$ & Nominal \\
\hline BEEXP & Experience about beekeeping & $\begin{array}{l}\text { If the experience about beekeeping is }<26 \text { years then he/she is experienced, if the } \\
\text { experience about beekeeping is }>25 \text { years, then he/she is very experienced }\end{array}$ & Numeric \\
\hline FAM & Household population & $\begin{array}{l}\text { If the household population is }<4 \text {, then it is a small family, if the household } \\
\text { population is }>3 \text { then it is a big family }\end{array}$ & Numeric \\
\hline
\end{tabular}

\subsection{The method employed in the analysis of the data}

A scale consisting of a total of 16 items was developed to determine beekeepers' attitudes towards agricultural cooperatives. The scale items were designed in the form of a five-point-Likert scale and the response options were designed as " 1 . Strongly disagree", "2. Disagree", “3. Moderately agree", "4. Agree", "5. Strongly agree" to elicit the participating farmers' attitudes towards the effect size of each item.

The decision tree model was used to determine the factors that affect the beekeepers' membership to the cooperative. In the current study, J48, naive bayes and random forest algorithms was used.

The decision tree is similar to the tree structure that has different nodes, such as root nodes, stem nodes, and leaf nodes. It is a frequently used technique in data mining for classifying a large amount of data and creating a data set with a similar structure (Ramya et al. 2018). One of the most widely used machine learning algorithms is the decision tree. When the literature is examined, it is seen that the decision tree method is widely used in different disciplines ranging from agricultural sciences to health sciences, social sciences to veterinary medicine.

This method systematically analyses data to derive important relationships between dependent variables and independent variables and to display them in a tree structure. The tree consists of nodes, branches and leaves (Rondovic 2019). At the top is the root node. In this node, a number of properties are tested and branches are derived from the root node according to the different results of this test. Each branch is connected to a new decision node and a new set of properties is tested to extract branches from these nodes. At the bottom of the tree structure are there leaf nodes from which no nodes are derived any more (Seyrek \& Ata 2010). During the construction of the decision trees, it is of great importance to determine from which property to start branching; that is, division. The branching of the tree can be carried out according to the value that the entropy will take. The entropy is expressed as follows (Özkan 2016):

$$
H(T)=-\sum_{i=1}^{n} p_{i} \log _{2}\left(p_{i}\right)
$$

In the $2^{\text {nd }}$ Equation, $\mathrm{T}$ stands for entropy, $p_{i}$ represents the likelihood of the presence of the $i$. data class found in the data set in the whole class (Bulut 2017). 


\section{Results and Discussion}

\subsection{Some socio-economic features of the beekeepers}

The ages of the beekeepers are between 27 and 74 and the mean age is 48.1 . In the study by Kizılaslan \& Adıgüzel (2012), the mean age of the beekeepers was found to be 51.70. The mean year of education of the beekeepers was found to be 5.9 years. Demirbük \& Kizılaslan (2020) found that $66.1 \%$ of the farmers are elementary school graduates, $23.8 \%$ are high school graduates, $6.5 \%$ are university graduates and 3.6\% do not have any education. The mean number of family members is 3.6 persons. The mean agricultural experience of the beekeepers was found to be 26.3 while their mean beekeeping experience is 19.5 years. Farmers need working capital to supply inputs. For farmers who lack adequate financial resources, credit is an alternative source of finance. Of the participating beekeepers, $64.5 \%$ were found to have used credit.

Of the participating beekeepers, $88.7 \%$ (55 farmers) are engaged in other agricultural activities apart from beekeeping, $38.1 \%$ of the total agricultural income of the participating beekeepers comes from beekeeping activities and $25.8 \%$ of them have other income sources different from agriculture.

\subsection{Findings related to the beekeepers' cooperative membership}

Agricultural cooperatives include agricultural development cooperatives, agricultural credit cooperatives and agricultural sales cooperatives (Kizılaslan \& Kizılaslan 2007). Agricultural development cooperatives are cooperatives founded to develop their members' production in many different product areas including plant production, animal production and forestry production, to conduct activities required to meet their members' needs for supplies, processing, marketing and evaluation, to help their economic and social development, to provide different lines of business, to make use of natural resources to increase their economic power and to be engaged in activities to promote the development of hand and home arts and agricultural industry (Can et al. 2017). Agricultural credit cooperatives are agricultural organizations that provide credit to their members under favourable conditions. The most important goal of agricultural sales cooperatives is to assist their members in marketing; that is, to find the best sales offers for the products of farmers in domestic and foreign markets.

One of the farmers' organizations is the producer associations. Producer associations have many different objectives such as to ensure the development of agricultural production, to provide technical and economic guidance to producers for this purpose, to provide producers with all kinds of agricultural inputs under appropriate conditions, to protect the rights of producers, to make necessary inquiries, to perform farmer training and extension services (Kızılaslan \& Doğan 2013).

Of the participating beekeepers, $48.4 \%$ are members of agricultural cooperatives while $51.6 \%$ are not members. When the agricultural cooperatives of which the beekeepers are member are examined, it is seen that $13.3 \%$ of them are members of agricultural development cooperatives, $83.4 \%$ are member of agricultural credit cooperatives and $3.3 \%$ are members of agricultural sales cooperatives. As can be seen, there are significant differences between the beekeepers' rates of membership in agricultural cooperatives. The biggest reason for this difference is thought to be the difference in the need of beekeepers for the services of the cooperatives. Many of the beekeepers are members of agricultural credit cooperatives. This shows that a significant portion of the beekeepers who are involved in the current research need agricultural credit. On the other hand, $82.3 \%$ of the beekeepers were found to be member of the Beekeepers' Association. The farmers who are not members of any cooperative were asked "Do you want to be a member to any cooperative in the future?". To this question, $56.2 \%$ of the beekeepers said "yes" while 43.8\% said "no". Among the reasons for the beekeepers' not being a member to any agricultural cooperative, the most prominent one is that there is no cooperative in the village (25.0\%), followed by the lack of trust in agricultural cooperatives $(21.9 \%)$ and inadequate number of hives $(21.9 \%)$.

A significant number of farmers think that cooperatives support farmers in terms of competitiveness (4.02), contribute to their bargaining power (3.98) and help farmers in getting credit (3.95).

\subsection{Results related to the decision tree}

In order to determine the success in classification, the test and training clusters were determined through 3 different processes. In the first process, the data set was divided by using the percentage split. In the percentage split method, $66 \%$ of the data set was used for training and $34 \%$ for the test. In the second process, the 10 fold cross validation method and in the third process, the 3 fold cross validation method were used. For the success in classification, the accuracy criterion was used. Moreover, kappa statistics, Mean Absolute Error (MAE) and Root Mean Square Error (RMSE) values of the models were investigated.

The percentage split method was found to have yielded a higher rate of accuracy than the cross validation methods. Naive bayes algorithm was found to have yielded the highest rate of accuracy. For example, for the naive bayes algorithm in the percentage split method, the rate of accuracy was found to be $76.1905 \%$. 
Kappa statistics (kappa coefficient) is used to measure the compliance between the observations. 1 shows a perfect compliance (Vierra \& Garrett 2005). In the current study, the highest kappa statistics value (0.5249) was obtained for the naive bayes algorithm in the percentage split method (Table 2).

MAE is used to determine the absolute error between the measurement values and model predictions. The closer the MAE value to zero, the better the prediction ability of the model is (Eren \& Eyüboğlu 2011). The lowest MAE value (0.3505) was obtained for the $\mathrm{J} 48$ algorithm in the percentage split method in the current study (Table 2).

RMSE is used as the error ratio between the measurement values and model predictions and a RMSE value converging to zero indicates increasing prediction ability of the model (Eren \& Eyüboğlu 2011). The lowest RMSE value (0.4319) was obtained for the random forest algorithm in the percentage split method in the current study (Table 2).

Table 2- Values of Kappa statistics, MAE and RMSE

\begin{tabular}{|c|c|c|c|}
\hline & \multicolumn{3}{|c|}{ Kappa statistics } \\
\hline & $\mathrm{J} 48$ & Naive bayes & Random forest \\
\hline Percentage split & 0.4324 & 0.5249 & 0.4324 \\
\hline 10 folds CV & 0.2282 & 0.3582 & 0.0921 \\
\hline \multirow[t]{3}{*}{3 folds $\mathrm{CV}$} & 0.0996 & 0.1935 & 0.1236 \\
\hline & \multicolumn{3}{|c|}{$M A E$} \\
\hline & $\mathrm{J} 48$ & Naive bayes & Random forest \\
\hline Percentage split & 0.3505 & 0.3592 & 0.3777 \\
\hline 10 folds CV & 0.4581 & 0.4113 & 0.4127 \\
\hline \multirow[t]{3}{*}{3 folds CV } & 0.4587 & 0.4279 & 0.4532 \\
\hline & \multicolumn{3}{|c|}{ RMSE } \\
\hline & $\mathrm{J} 48$ & Naive bayes & Random forest \\
\hline Percentage split & 0.4845 & 0.4344 & 0.4319 \\
\hline 10 folds CV & 0.5729 & 0.4888 & 0.4652 \\
\hline 3 folds CV & 0.5938 & 0.5051 & 0.5047 \\
\hline
\end{tabular}

In the current study, in order to construct the decision tree, a total of 13 independent variables that are the beekeeper's age, the beekeeper's agricultural experience, the beekeeper's status of having out of agricultural income, the beekeeper's number of hives, the beekeeper's education level, the beekeeper's state of using credit, the beekeeper's state of storing honey, the state of beekeepers' having access to beekeeping data, their state of needing data about beekeeping, producers' experiences of beekeeping, household population, the beekeeper's state of adopting innovations, the beekeeper's state of receiving beekeeping supports were included in the model. However, as a result of the analysis conducted, it was determined that there are three variables in the decision tree that are the beekeeper's state of using credit, the beekeeper's education level and the beekeeper's state of receiving beekeeping supports (Figure 1).

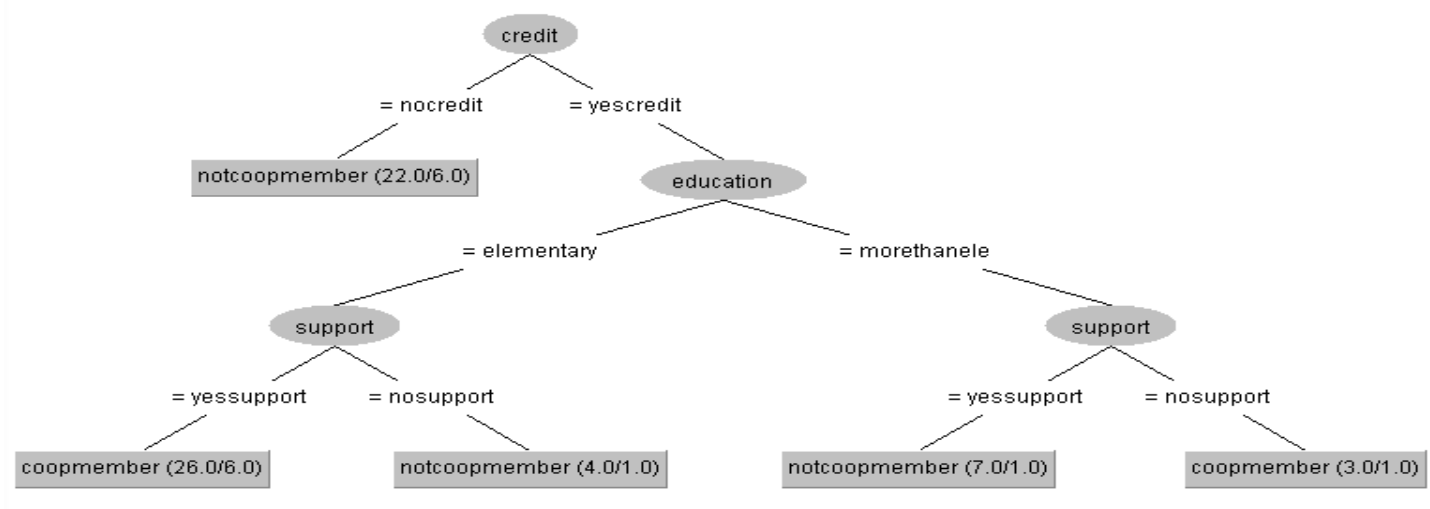

Figure 1- The decision tree for the factors affecting the membership to cooperatives

The decision tree produces rules. The decision tree obtained in the current study was found to have produced five rules. These rules produced by the decision tree are shown below. Weka software was used in the analysis.

\footnotetext{
Rule 1: If it is =nocredit then notcoopmember

Rule 2: If it is =yescredit and=elementary and =yessupport then coopmember

Rule 3: If it is =yescredit and =elementary and =nosupport then notcoopmember
} 
Rule 4: If it is =yescredit and =morethanele and =yessupport then notcoopmember

Rural 5: If it is =yescredit and =morethanele and =nosupport then coopmember

The important point to be taken into consideration here is not to evaluate the individual variables within a rule separately, but to evaluate the variables within a rule together. For example, when Rule 2 and Rule 4 are examined, it is seen that the status of being a member of a cooperative changes due to the difference in education level.

In the decision tree, first the beekeepers' status of using credit was examined. The beekeepers not using credit are not members to cooperatives. Then, a classification of the beekeepers using credit was made according to their education level. Thus, these beekeepers were divided into two classes as those having elementary education and those having education more than elementary education. If the beekeepers having elementary education are receiving beekeeping support then they are cooperative members. If the beekeepers having elementary education do not receive beekeeping support then they are not cooperative members. If the beekeepers having education more than elementary education receive beekeeping support then they are not cooperative members. If the beekeepers having education more than elementary education do not receive beekeeping support then they are cooperative members.

In the current study conducted to determine the factors affecting the cooperative membership of the farmers working in the Milas district, it was found that education level of the beekeepers is highly influential on their decision to be a cooperative member. Ogunleye et al. (2015), Anigbogu et al. (2017) reported similar results. In these studies, it was also found that the farmers' education level affects their cooperative membership.

In the present study it was also found that the beekeepers' state of receiving beekeeping supports affects their membership to a cooperative. Ertek et al. (2016) found that the amount of the support received by the producers affects their decision to be a member of a cooperative. Similarly, in a study conducted by Debeb \& Haile (2016), the amount of the support received was found to be positively affecting the membership to a cooperative.

When the decision tree was structurally examined, it was determined that the producers with primary education and beekeeping support were cooperative members and the producers with higher levels of education and receiving beekeeping support were not cooperative members. These findings clearly show that the factors affecting the beekeepers' cooperative membership are the level of education and beekeeping supports.

Another factor found to be influential on the farmers' membership to a cooperative in the current study is their status of using credit. When the decision tree was structurally examined, it was found that the beekeepers not receiving credit are not cooperative members. This result concurs with the findings of Gashaw \& Kibret (2018), Omotesho et al. (2016).

In the current study, it was determined that only three of the 13 variables used in the decision tree model had an effect on the cooperative membership of beekeepers. When the relevant literature was reviewed, it was found that many different variables have an effect on the membership of farmers in a cooperative. In fact, this is an expected result because the personality characteristics of farmers, farmers' perspective on cooperatives, examples of successful/unsuccessful cooperatives, cooperative subsidies, production patterns and agricultural structure can vary greatly from country to country.

The main advantage of decision tree classifiers is their capability to break down a complex structure into a collection of simpler structures, thus providing a solution that is easy to interpret (Cho et al. 2011). Another advantage of decision-tree approach is it visualizes the solution; it is easy to follow any path through the tree (Wang \& Lee 2006). When the previous studies on the subject were examined, many studies using decision tree method in beekeeping were found. In a study conducted by Edwards-Murphy et al. (2016), the decision tree method was used in the monitoring of honey bee health. In a study conducted by Aksoy et al. (2018), some data mining algorithms such as MARS and CHAID were used to produce honey production estimates of beekeeping enterprises. In a study conducted by Karadas \& Kadirhanogullari (2017), data mining and artificial neural network algorithms were used to determine the amount of honey production. When a general evaluation was made, it was determined that the studies using data mining methods in beekeeping were mostly for estimating the amount of honey production, and the data mining methods were not used sufficiently in the studies to determine beekeepers' perspectives of cooperatives. This current study is seen to be important as it is believed to fill this void in the literature.

\section{Conclusions}

The beekeepers participating in the current study were found to be middle-aged, elementary school graduates and engaged in beekeeping for a long time in general. In the current study, the beekeepers' education level was found to have a positive influence on their cooperative membership. As it will be difficult to give formal education to these farmers, their education level should be increased through informal education. For this reason, farmer training should be carried out through agricultural extension activities. 
In light of the findings of the current study, it can be argued that the cooperative membership ratio of the farmers is not very high. It was also found that the beekeepers do not have much information about cooperatives and they do not much trust in cooperatives. Therefore, a comprehensive extension and training program including information about why cooperatives are established and their economic and social impacts.

High majority of the farmers were found to be members of the Beekeepers' Association. On the other hand, there are three different cooperatives of which beekeepers are members, which shows that there is an awareness of cooperatives in the district. Therefore, through effective agricultural policies and support programs to be implemented, more beekeepers are believed to be convinced for cooperative membership.

In the current study, it was determined that decision tree algorithms can be used to determine the factors affecting the cooperative membership of beekeepers. Therefore, it is thought that the results of this study will provide guidance for other studies to be conducted on the subject. On the other hand, in order to increase the accuracy rate in decision tree models, it is planned to add some variables to the model by increasing the number of questionnaires in future studies.

\section{Acknowledgements}

We wish to thank all farmers that participated in our study.

\section{References}

Aksoy A, Sar1 M M \& Terin M (2017). Economic structure of beekeeping sector in Erzurum province. Turkish Journal of Agricultural and Natural Sciences 4(4): 434-440

Aksoy A, Ertürk Y E, Erdoğan S, Eyduran E \& Tariq M M (2018). Estimation of honey production in beekeeping enterprises from eastern part of Turkey through some data mining algorithms. Pakistan Journal of Zoology 50(6): 2199-2207 http://dx.doi.org/10.17582/journal.pjz/2018.50.6.2199.2207

Anigbogu T U, Agbasi O E \& Okoli I M (2017). Socioeconomic determinants of farmers membership of cooperative societies in Anambra State, Nigeria. International Journal for Innovative Research in Multidisciplinary Field 3(12): 13-20

Balgah R A (2019). Factors influencing coffee farmers' decisions to join cooperatives. Sustainable Agriculture Research 8(1): 42-58 https://doi.org/10.5539/sar.v8n1p42

Bernard T \& Spielman D J (2009). Reaching the rural poor through rural producer organizations? A study of agricultural marketing cooperatives in Ethiopia. Food Policy 34: 60-69 https://doi.org/10.1016/j.foodpol.2008.08.001

Bulut F (2017). Different mathematical models for entropy in information theory. Bilge International Journal of Science and Technology Research 1(2): 167-174 (In Turkish)

Can B A, Engindeniz S \& Can O (2017). The role and importance of cooperatives in rural development: the case of Çavuşlu agricultural development cooperative with limited liability. Third Sector Social Economic Review 52:120-139 (In Turkish)

Cho Y J, Lee H \& Jun C H (2011). Optimization of decision tree for classification using a particle swarm. Industrial Engineering and Management Systems 10(4): 272-278

Debeb D \& Haile M (2016). A study on factors affecting farmers' cooperative membership increment in Bench Maji Zone, Southwestern Ethiopia. Developing Country Studies 6(2): 129-138

Demirbük M \& Kizılaslan N (2020). Analysis of relationships between breeders' associations and their, a case study of Sivas. Kahramanmaraş Sütçü İmam University Journal of Agriculture and Nature 23(1): 194-211(In Turkish) https://doi.org/10.18016/ksutarimdoga.vi.562087

Dorgi O \& Gala G (2016). Assessment of factors affecting members' participation in fishery cooperatives (the case of Gambella Region, Ethiopia). Journal of Business Management \& Social Sciences Research 5(12): 347-363

Edwards-Murphy F, Magno M, Whelan P M, O’Halloran J \& Popovici E M (2016). b+WSN: Smart beehive with preliminary decision tree analysis for agriculture and honey bee health monitoring. Computers and Electronics in Agriculture 124: 211-219 https://doi.org/10.1016/j.compag.2016.04.008

Eren B \& Eyüpoğlu V (2011). Modelling of recovery efficiency of Ni (II) ion using artificial neural network. In: Proceedings of the $6^{\text {th }}$ International Advanced Technologies Symposium, 16-18 May, Elazı̆ $\breve{g}, p p .186-190$

Ertek N, Demir N \& Aksoy A (2016). Analysis of the factors affecting the cooperative membership of the cattle enterprises: the case of TRA region. Alinteri Journal of Agriculture Science 30(1): 38-45 (In Turkish)

Gashaw B A \& Kibret S M (2018). Factors influencing farmers' membership preferences in agricultural cooperatives in Ethiopia. American Journal of Rural Development 6(3): 94-103 https://doi.org/10.12691/ajrd-6-3-4

Genç Y, Albayrak M \& Güldal H T (2020). Analysis of factors affecting consumption preferences in fish consumption: Case of Çankırı province. Ege Journal of Fisheries and Aquatic Sciences 37(1): 93-101 (In Turkish) https://doi.org/10.12714/egejfas.37.1.11

Gutierrez J D (2014). Smallholders' agricultural cooperatives in Colombia: ¿vehicles for rural development?. Revista Desarrollo y Sociedad 73: 219-271 https://doi.org/10.13043/DYS.73.7

Karadas K \& Kadırhanogullari I H (2017). Predicting honey production using data mining and artificial neural network algorithms in apiculture. Pakistan Journal of Zoology 49(5): 1611-1619 http://dx.doi.org/10.17582/journal.pjz/2017.49.5.1611.1619

Karlı B, Bilgiç A \& Çelik Y (2006). Factors affecting farmers' decision to enter agricultural cooperatives using random utility model in the South Eastern Anatolian Region of Turkey. Journal of Agriculture and Rural Development in the Tropics and Subtropics 107(2): 115-127

Kizılaslan N \& Adigüzel F (2012). Analysis of organizational commitment of members of Tokat central beekeepers union to general association. Journal of Agricultural Faculty of Gaziosmanpasa University 29(1):13-27 (In Turkish)

Kizılaslan H \& Doğan H G (2013). Importance and status of producer unions in the producer organizations of Turkey (a case study with fresh vegetable and fruit producers organization of Kazova region in Tokat province). Akademik Bakış. Journal 38: 1-17 (In Turkish)

Kızılaslan N \& Gürler A Z (1997). Agricultural development cooperatives member producers affecting your participation in the cooperative social and economic factors econometric analysis in Tokat central district. Third Sector Cooperative 118: 5-29 (In Turkish) 
Kızılaslan H \& Kizılaslan N (2007). Factors affecting honey production in apiculture in Turkey. Journal of Applied Sciences Research 3(10): 983-987

Liu Y (2018). Determinants and impacts of marketing channel choice among cooperatives members: Evidence from agricultural cooperative in China. In: Proceedings of the 10 International Conference of Agricultural Economists, July 28-Agust 2, Vancouver, pp. 1-37

Mojo D, Fischer C \& Degefa T (2015a). Who benefits from collective action? Determinants and economic impacts of coffee farmer cooperatives in Ethiopia. In: Proceedings of the Agriculture in an Interconnected World, 8-14 August, Milano, pp. 1-33

Mojo D, Fischer C \& Degefa T (2015b). Social and environmental impacts of agricultural cooperatives: evidence from Ethiopia. International Journal of Sustainable Development \& World Ecology 22(5): 388-400 https://doi.org/10.1080/13504509.2015.1052860

Niyaz Ö C \& Demirbaş N (2018). Food safety perceptions of fresh fruits and vegetables consumers. Journal of Tekirdag Agricultural Faculty 15(02): $36-44$

Ogunleye A A, Oluwafemi Z O, Arowolo K O \& Odegbile O S (2015). Analysis of socio economic factors affecting farmers participation in cooperative societies in Surulere Local Government Area of Oyo State. Journal of Agriculture and Veterinary Science 8(5): 40-44 https://doi.org/10.9790/2380-08514044

Omotesho K F, Ogunlade I, Lawal M A \& Kehinde F B (2016). Determinants of level of participation of farmers in group activities in Kwara State, Nigeria. Journal of Agricultural Faculty of Gaziosmanpasa University 33(3): 21-27 https://doi.org/10.13002/jafag887

Özkan Y (2016). Data Mining Methods (Third Edition). Papatya Publishing, İstanbul

Ramya Y, Kumar P, Mugilan D \& Babykala M (2018). A review of different classification techniques in machine learning using weka for plant disease detection. International Research Journal of Engineering and Technology 5(5): 3818-3823

Rondovic B, Djurickovic T \& Kascelan L (2019). Drivers of e-business diffusion in tourism: a decision tree approach. Journal of Theoretical and Applied Electronic Commerce Research 14(1): 30-50 https://doi.org/10.4067/S0718-18762019000100104

Seyrek İ H \& Ata H A (2010). Efficiency measurement in deposit banks using data envelopment analysis and data mining. Journal of BRSA Banking and Financial Markets 4(2): 67-84 (In Turkish)

Viera A J \& Garrett J M (2005). Understanding inter observer agreement: the kappa statistic. Society of Teachers of Family Medicine 37(5): 360-363

Wang T C \& Lee D D (2006). Constructing a fuzzy decision tree by integrating fuzzy sets and entropy. In: Proceedings of the Proceedings of the $5^{\text {th }}$ WSEAS International Conference on Applied Computer Science, Hangzhou pp. 1-3

Woldu T, Tadesse F \& Waller M K (2013). Women's Participation in Agricultural Cooperatives in Ethiopia. - ESSP Working Paper 57: $22 \mathrm{p}$

(C) 2022 by the author(s). Published by Ankara University, Faculty of Agriculture, Ankara, Turkey. This is an Open Access article distributed under the terms and conditions of the Creative Commons Attribution (CC BY) license (http://creativecommons.org/licenses/by/4.0/), which permits unrestricted use, distribution, and reproduction in any medium, provided the original work is properly cited. 